\title{
Marketing Planning as a Tool to Augment the Visitation of Heritage Sites and Museums ${ }^{1}$
}

\author{
Mohamed Amer ${ }^{2}$
}

\begin{abstract}
Heritage, either tangible or intangible, is considered a tool for preserving the inherited past, which forms the present identity, into the distant future for the new generations. Regarding our current socio-cultural needs, the word "Heritage" contributes promoting the image of cultural landscapes, heritage sites, or museums. These heritage attractions are the places where the people can realize the past and communicate emotionally with the heritage area. This paper views the concept of heritage marketing as a process augmenting the visitation of cultural landscapes, heritage sites, or museums. At the same time, it compiles a couple of marketing techniques strengthening the visitor's satisfaction, within the appropriate offered programs, via selecting the exact target audience. After reviewing the literature, it was found out that heritage marketing is focused on promoting and representing the values of heritage attractions, while there is no main structure or a developed framework for the marketing plan of cultural heritage destinations. As a result, this research aims to fill in this academic and professional gap interpreting the main steps of heritage marketing plan.
\end{abstract}

\section{Keywords}

Heritage Management - Heritage Sites - Museums - Heritage Economic - Heritage Marketing

\section{Introduction}

According to UNESCO World Heritage Center, "a site's inscription on the World Heritage List often coincides with a boost in visitation rates" 3 . Although there are heritage attractions which are inscribed in World Heritage List (WHL), these sites, as well as another heritage sites and museums in general, apparently are not well promoted. So, the absence of planned marketing techniques resulted in not only the decreased market position of the heritage sites and museums but their overall image as well. Consequently, the number of visitors becomes a great challenge as the site could suffer acute decrease in revenues necessary for both its preservation and sustainability; and therefore, to loss the integrity and authenticity.

This paper is probably among the first attempts to address the plan of marketing in the heritage sites and museums in general. Although there are few published researches in relation to this perspective "Heritage Marketing", there are some authors who have generally been writing about it and its methods such as Shashi Misiura (2006); Neil G. Kotler, Philip Kotler, and Wendy I. Kotler (2008); and Hyung Yu Park (2014).

This developed structure of heritage marketing plan has an appropriate significance. It promotes the site's culture significance augmenting the visitation rate especially during off-peak times; managing a demand; as well as avoiding adverse impacts on the heritage site or museum.

\footnotetext{
${ }^{1}$ This paper was divided from a dissertation of Master of Arts in Heritage Conservation and Site Management, that has jointly been held between Helwan University (Egypt) and Brandenburg University of Technology Cottbus-Senftenberg (Germany), "Developing Innovative Marketing Plan to Augment the Visitation of Egyptian World Heritage Sites: A Case Study on Saladin Citadel'. In order to review the whole heritage marketing project, let's go to this link (www.researchgate.net/publication/291832778)

${ }^{2}$ Heritage Management Professional and Founder of “HeritageForAll” Initiative (mohammadbadry2013@gmail.com)

${ }^{3}$ Arthur Pedersen, Managing Tourism at World Heritage Sites: a Practical Manual for World Heritage Site Managers, vol. WH Manuals 1 (Paris: UNESCO WHC, 2002), accessed June 26, 2015, http://whc.unesco.org/uploads/activities/documents/activity-1132-.pdf.
} 


\section{Marketing and Cultural Heritage}

Cultural heritage is considered a unique context which requires taking into consideration a special foresight to manage and market it. It has a high significance in the lives of the majority of people and they have a great willingness to preserve it ${ }^{4}$. So, a cultural heritage, either tangible or intangible heritage, is considered a tool ${ }^{5}$ of technically preserving the inherited past which forms the present ${ }^{6}$. The heritage site or museum contributes particularly in reforming the identity into the framework of our current socio-cultural needs ${ }^{7}$. Shashi Misiura identified the heritage site, based on the quotation by the British Tourist Authority (2000) in Travel and Tourism Analyst, as a constant picnic area and something which is considered a tool of entertaining the public and communicating with them in educational way ${ }^{8}$.

He continued by mentioning that cultural heritage, represented in the national history and local folklore, is considered one of the cultural attractions which supports the tourism industry within the heritage framework. He placed a great emphasis on the significance of heritage sites giving the example of visiting "Open Air Museums" which aim to raise an awareness of the individuals of the community. ${ }^{9}$ Moreover, according to the direct observation of Yaniv Poria, Richard W. Butler, and David Airey, the heritage attractions are the places where the people can realize the past and communicate emotionally with their heritage $^{10}$. Consequently, the word "heritage" contributes effectively to promote the image of a heritage attraction ${ }^{11}$.

\section{Heritage Marketing}

In a business framework, marketing as a science is a great process. Respectively, American Marketing Association (AMA) and Philip Kotler identify it as "the process of planning and executing the conception, pricing, promotion, and distribution of ideas, goods, and services to create exchanges that satisfy individual (customer) and organizational objectives" ${ }^{12}$. Kotler indicates to the interaction between the marketing concept and the customer that marketing acts as a tool to assist the public "exchange something of value for something they need or want"13.

According to this definition, heritage destinations and visitors are utilised together by the marketing operation because they simultaneously exchange their needs and wants. Consequently, Lertkulprayad confined the definition of heritage marketing as an operation of strengthening the visitor's satisfaction, within the appropriate offered programs, via selecting the exact target audience $^{14}$.

On the other hand, Uzi Baram and Yorke Rowan reform the interaction and relationship between the heritage framework and the marketing process. The interaction and relationship divide from the main role which the marketing process plays. Marketing invests the emotional rapport linking between the past representatives and manifestations and the present life. Respectively, the heritage site or museum will have the ability of attracting who like and prefer spending his/her spare time in a cultural heritage atmosphere. And therefore, the archaeological or heritage assets generate inflow and financially support the projects that have to happen such as conservation; capacity building; visitor facilities and implementing the management plan. ${ }^{15}$

\footnotetext{
${ }^{4}$ Shashi Misiura, Heritage Marketing, $1^{\text {st }}$ ed. (London: Routledge, 2006), 9.

${ }^{5}$ A cultural heritage is a main body to eternize the human memory along the coming human generations. So, author uses here the technical word «tool». ${ }^{6}$ Gregory Ashworth and Peter Howard, eds., European Heritage Planning and Management (Bristol: Intellect Ltd, 1999); Misiura, Heritage Marketing, 9. ${ }^{7}$ Laurajane Smith, “Theorizing Museum and Heritage Visiting," in The International Handbooks of Museum Studies: Museum Theory, ed. Andrea Witcomb and Kylie Message, $1^{\text {st }}$ ed., vol. 1 (Chichester, West Sussex: John Wiley \& Sons, Ltd, 2015), 460.

${ }^{8}$ Smith, "Theorizing Museum and Heritage Visiting," 146-48.

${ }^{9}$ Smith, "Theorizing Museum and Heritage Visiting," 156

${ }^{10}$ Yaniv Poria, Richard W. Butler, and David Airey, “The Core of Heritage Tourism," Annals of Tourism Research 30, no. 1 (2003): 238-54; Smith, "Theorizing Museum and Heritage Visiting," 459.

${ }^{11}$ Hyung Yu Park, Heritage Tourism, $1^{\text {st }}$ ed. (London ; New York: Routledge, 2014), 134.

12 “Definition of Marketing and Management," UKEssays, accessed June 26, 2015, www.ukessays.com/essays/marketing/definition-of-marketing-andmanagement-marketing-essay.php; Philip Kotler, Marketing Essentials (Englewood Cliffs: Prentice-Hall, 1984), 92.

${ }^{13}$ Hugh H. Genoways and Lynne M. Ireland, Museum Administration: an Introduction (Walnut Creek, Calif: AltaMira Press, 2003), 247; Philip Kotler, Marketing Management: Analysis, Planning, Implementation and Control, $9^{\text {th }}$ ed. (Upper Saddle River, NJ: Prentice Hall College, 1999), 6.

${ }^{14}$ Lamson Lertkulprayad, “Marketing Cultural Heritage to Promote Tourism Growth in Areas of Low Tourism Patronage: Case Study of Phetchaburi Province’s Downtown” (PhD, Silpakorn University, 2007), 31.

${ }^{15}$ Uzi Baram, "Marketing Heritage," ed. Claire Smith, Encyclopedia of Global Archaeology, 2014, 4674; Yorke Rowan and Uzi Baram, "Archaeology after Nationalism: Globalization and the Consumption of the Past," in Marketing Heritage: Archaeology and the Consumption of the Past, ed. Yorke Rowan and Uzi Baram (Oxford: AltaMira Press, 2004), 5.
} 
Completing the previous approach, Park interpreted two exchanged factors value for money and edutainment ${ }^{16}$, which through, marketing deals with heritage sites. Visitors are paying an admission fees and are expecting to be provided with an experience. Consequently, heritage marketing is seeking to utilize commercial approaches with heritage destination. ${ }^{17}$

In contrast, there are some scholars, like Ruth Rentschier, who oppose the previous discussion considering the term "marketing" not to be generally an appropriate word in the context of cultural heritage and arts as it is a profitable expression, while heritage sites are often non-profit entities ${ }^{18}$.

\section{Heritage Marketing Function}

As a result of interacting between the heritage framework and the marketing process, the heritage marketing practically has various functions. It plays a main part of promoting the cultural heritage assets at the heritage sites and museums. It functionally creates a promotional context preparing the heritage site or museum to select its exact target market ${ }^{19}$. Completing the former perspective, Peter Fraser, Finola Kerrigan and Mustafa Özbilgin estimate its task in the frame of market researching to realize the visitors needs and wants and their rapport with the heritage site or museum ${ }^{20}$.

Misiura highlights other significant role of heritage marketing. He sees it as a guideline which has a main step to lead and learn how to control the site, via marketing objectives, in order to preserve the heritage site for future generations and at the same time, to satisfy the visitors' demands and expectations providing them with the suitable services ${ }^{21}$. Regarding the former concept, he disagrees with some international heritage entities which invest wrongly the heritage marketing process ${ }^{22}$. These entities target generating inflow in order to financially upgrade the rate of the heritage site or museum and at the same time, to provide the visitor's satisfaction. Therefore, all of these factors are overload and to impact effectively and dangerously on the factors of authenticity, integrity, and sustainability. Consequently, Rentschier attempted to re-correct the opinion of Misiura. Heritage marketing mission is mainly to consolidate the heritage visitors' experience; and to evaluate and enhance the portfolio of a heritage site or museum ${ }^{23}$.

Finally, the researcher quoted other functions of heritage marketing process that Kotler et al. articulated. Heritage marketing plays a part of boosting, upgrading or reducing the rate of visitors; professionally controlling the communications with the stakeholders; as well as simultaneously increasing site revenues. Furthermore, it determines the visitor desires and satisfies some of these offering various services, programs and activities that would enhance the visitors' experience. ${ }^{24}$

\section{How to develop a heritage marketing plan?}

Although there are few published references, books or articles which explain and clarify exactly and practically the steps of developing a heritage marketing plan, the author uses some features which were mentioned within some the business marketingrelated literatures, structures the main frame of developing a heritage marketing plan. R.A. Strang and J. Gutman; Genoways and Ireland; P.D. Searles; and Kotler et al. clarify the steps of developing a marketing plan as the following ${ }^{25}$ :

To begin, the marketer assesses the current marketing situation, and analyzes its context by scanning the micro and macro environment. Analysis could also be performed by doing a SWOT analysis (Strength, Weaknesses, Opportunities, and Threats);

\footnotetext{
${ }^{16}$ The term edutainment combines between the words «education» and «entertainment».

${ }^{17}$ Park, Heritage Tourism, 143.

${ }^{18}$ Ruth Rentschier, "Museum Marketing, Understanding Different Types of Audiences,” in Museum Management and Marketing, ed. Richard Sandell (London; New York: Routledge, 2007), 354.

${ }^{19}$ Deepak Chhabra, "Proposing a Sustainable Marketing Framework for Heritage Tourism," Journal of Sustainable Tourism 17, no. 3 (2009): 307; Park, Heritage Tourism, 138.

${ }^{20}$ Peter Fraser, Finola Kerrigan, and Mustafa Özbilgin, "Key Issues in Arts Marketing,” in Arts Marketing, ed. Finola Kerrigan, Peter Fraser, and Mustafa Özbilgin, $1^{\text {st }}$ ed. (Oxford: Routledge, 2004), 195.

${ }^{21}$ Misiura, Heritage Marketing, 2.

${ }^{22}$ Misiura, Heritage Marketing, 6

${ }^{23}$ Rentschier, "Museum Marketing, Understanding Different Types of Audiences," 354.

${ }^{24}$ Neil G. Kotler, Philip Kotler, and Wendy I. Kotler, Museum Marketing and Strategy: Designing Missions, Building Audiences, Generating Revenue and Resources, $2^{\text {nd }}$ ed. (San Francisco: Jossey-Bass, 2008), 2123-; 30, 31.

${ }^{25}$ Genoways and Ireland, Museum Administration, 253-56; Misiura, Heritage Marketing, 157; P.D. Searles, "Marketing Principles and the Arts," in Marketing the Arts, ed. Michael P. Mokwa, William M. Dawson, and E. Arthur Prieve (New York: Praeger Publishers, 1980), 67; R. A. Strang and J. Gutman, "Promotion Policy Making in the Arts," in Marketing the Arts, ed. Michael P. Mokwa, William M. Dawson, and E. Arthur Prieve (New York: Praeger Publishers, 1980), 226, 227.
} 
a marketing mix including the 4Ps (Product, Place "Distribution Channels", Price and Promotion); to assess the competition situation; and the target segmentation or market of the heritage site or museum.

Second, the marketer identifies the marketing strategies, which any destination should follow regarding "its product portfolio", as well as its goals, objectives and actions for estimating the plan's aim, regarding the target customers' desires, in an effort to increase the rate or to maximize the generated income. Third, the marketer clarifies the needed budget to fulfill the plan and expect the expenses. Finally, he monitors or audits the plan's outcomes and its implementation.

Investing the former guidelines, research sets in depth the form of developing a heritage marketing plan as the following:

\section{First Step: Situation Analysis}

\section{A.SWOT Analysis}

The research adopted SWOT analysis to assess the status quo of the heritage site or museum identifying the micro and macro environments of the heritage attraction. A micro environmental scan assesses the internal factors including strengths and weaknesses, while a macro environmental scan analyses the external factors including opportunities and threats. Kotler et al. and Morrison recommend observing the PESTLE items (Political, Economic, Social, Technological, Legislative and Environmental) within the macro environmental scan ${ }^{26}$.

\section{B. Marketing Mix}

Kotler defined a marketing mix as "the mixture of controllable marketing variables that the firm uses to pursue the sought level of sales in the target market" ${ }^{27}$. Moreover, E. Jerome McCarthy; Stephen W. Boyd and Dallen J. Timothy; and Kotler et al. indicate that there are principle tools in order for the marketing mix to accomplish its task, which are known as the traditional 4. Ps including product, place "Distribution channels", price and promotion ${ }^{28}$. Alastair M. Morrison added extra elements such as "packaging, programming, partnership, and people" 29.

\section{Product}

Although there are some authors who perceive that marketing isn't an appropriate word and perspective in the cultural heritage context, there are others who operationalize the interaction between the marketing process and the cultural heritage considering it as a product. Misiura and Kotler et al. had identified the features of a cultural heritage product. Cultural heritage is both a physical and symbolic product represented in a heritage site or museum collection and has the function which is to enhance its visitors' experience ${ }^{30}$.

Moreover, a cultural heritage (tangible and intangible), either a product or a service, has a life cycle. This cycle is the main factor of reformatting a heritage product through numerous steps. Morrison logically explains this life cycle, by stating that the cycle "goes through the four stages of introduction, growth, maturity and decline"31, while R.W. Butler had seven levels for the life cycle of a heritage destination: "exploration, involvement, development, consolidation, stagnation, decline and rejuvenation" 32 .

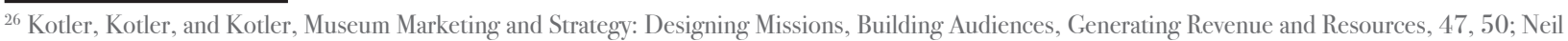
Kotler and Philip Kotler, "Can Museums Be All Things to All People? Mission, Goals, and Marketing's Role," in Museum Management and Marketing, ed. Richard Sandell (London; New York: Routledge, 2007), 328; Alastair M. Morrison, Marketing and Managing Tourism Destinations, $1^{\text {st }}$ ed. (New York: Routledge, 2013), 82 .

${ }^{27}$ Kotler, Marketing Essentials, 92; Park, Heritage Tourism, 133.

${ }^{28}$ Stephen W. Boyd, and Dallen J. Timothy, "Marketing Issues and World Heritage Sites," in Managing World Heritage Sites, ed. Anna Leask, and Alan Fyall, $1^{\text {st }}$ ed. (USA: Elsevier Ltd., 2006), 61; Fraser, Kerrigan, and Özbilgin, "Key Issues in Arts Marketing,” 195; Kotler, Kotler, and Kotler, Museum Marketing and Strategy: Designing Missions, Building Audiences, Generating Revenue and Resources, 29; Kotler, and Kotler, "Can Museums Be All Things to All People? Mission, Goals, and Marketing's Role,” 328; E. Jerome McCarthy, Basic Marketing: a Managerial Approach, $7^{\text {th }}$ ed. (Georgetown: Irwin, 1981).

${ }^{29}$ Alastair M. Morrison, Hospitality and Travel Marketing, $5^{\text {th }}$ ed. (Clifton Park, NY: Delmar Cengage Learning, 2010); Morrison, Marketing and Managing Tourism Destinations, 72 .

${ }^{30}$ Kotler, Kotler, and Kotler, Museum Marketing and Strategy: Designing Missions, Building Audiences, Generating Revenue and Resources, 28,29 ; Misiura, Heritage Marketing, 16, 131 .

${ }^{31}$ Morrison, Marketing and Managing Tourism Destinations, 70.

${ }^{32}$ R.W. Butler, “The Concept of A Tourist Area Cycle of Evolution: Implications for Management of Resources,” The Canadian Geographer 24, no. 1 (1980): 5-12; Morrison, Marketing and Managing Tourism Destinations, 70.
} 
For product as a marketing mix element, there are some authors who stated that it is "what is actually delivered to the consumer and the benefits that a consumer can gain to suit their needs and wants," including product planning, branding and packaging. So, for heritage, the heritage sites, the museum objects and also intangible heritage are considered the heritage products that visitorsdesire. ${ }^{33}$

\section{Place "Distribution Channels"}

Regarding the marketing framework, the concept of "place" means the distribution channels of the heritage product. There are two kinds of these distribution channels that the heritage sites or museums promote their property: either directly to visitors, eliminating the barriers via direct mail offerings, telemarketing, and e-commerce offerings or indirectly through intermediaries by wholesalers, retailers, and advertisements to motivate potential visitors to visit the site and enjoy its services and facilities ${ }^{34}$.

\section{Price}

The price is the cost of the heritage visit administrating the relationship between the visitors and the economic objectives of the heritage attraction. The marketing mix element of price has both negative and positive aspect, and can at the same time attract or repel certain target groups ${ }^{35}$.

To give one example, when the team of National Organization for Urban Harmony (NOUH) had done a questionnaire that targeted Saladin Citadel visitors, they could estimate "the tourists" willingness to pay a higher visitation fees to the Citadel for a much richer historical and cultural tourism product". The majority of site visitors $(80 \%)$ agreed while there are many visitors $(20 \%)$ who stated that "it would depend on the amount of the increase" 36 . There are some countries worldwide which allow the visitor to enter heritage attractions free of charge, for instance, the British Museum. Additionally, "Hoggard ${ }^{37}$ highlighted the efforts of a whole range of UK arts institutions to provide cheaper ticket prices. Many accept that price represents a serious barrier to arts attendance" 38 .

\section{Promotion}

The element of promotion is considered one of the main actions of a heritage destination marketing operation, which displays the added-value benefits of heritage attractions for heritage visitors through multi-variables such as advertising, using digital and IT marketing techniques, sales or direct marketing, and public relations. For example, some countries worldwide even use being a WHS as a brand to market their activities, offers, and projects related to sites on the WHL ${ }^{39}$.

Heritage visitors have their main expectations and motivations to which they aspire by connecting and exchanging their need and wants with the heritage attraction. As a result, the heritage marketer, as an ethnographer, should realize these motivations. Satisfying these expectations, there are some heritage marketers who invest tangibility, e.g. accessibility, and educational opportunities, and intangible insights, i.e. "the appropriateness of using (modern / up-to-date) technology", of the heritage attraction in order to boost the visitor numbers to the heritage destination. ${ }^{40}$

Providing the former methodologies, there are various tools which assist the heritage marketer to promote the heritage sites. These marketing tools are not only short-term, like organising exhibitions, educational activities, creating websites, social

\footnotetext{
${ }^{33}$ Kotler, Kotler, and Kotler, Museum Marketing and Strategy: Designing Missions, Building Audiences, Generating Revenue and Resources, 28; Misiura, Heritage Marketing, 130; Boyd and Timothy, "Marketing Issues and World Heritage Sites,” 61, 62.

${ }^{34}$ Boyd and Timothy, "Marketing Issues and World Heritage Sites," 62; Kotler, Kotler, and Kotler, Museum Marketing and Strategy: Designing Missions, Building Audiences, Generating Revenue and Resources, 96.

${ }^{35}$ Boyd and Timothy, "Marketing Issues and World Heritage Sites," 62; Fraser, Kerrigan, and Özbilgin, "Key Issues in Arts Marketing," 196.

${ }^{36}$ Hesham Mohamed El-Barmelgy, "Visitor Management Plan and Sustainable Culture Tourism (Presenting the VMP Project for the Cairo Citadel of Salah El Dien)," International Journal of Education and Research 1, no. 12 (2013): 168.

${ }^{37}$ Liz Hoggard, "Arts on the Cheap," The Guardian (Culture - The Observer), February 9, 2003, accessed April 20, 2015, www.theguardian.com/ theobserver $/ 2003 /$ feb/09/features.review3 3 .

${ }^{38}$ Fraser, Kerrigan, and Özbilgin, “Key Issues in Arts Marketing," 196.

${ }^{39}$ Morrison, Hospitality and Travel Marketing, 62; Kotler, Kotler, and Kotler, Museum Marketing and Strategy: Designing Missions, Building Audiences, Generating Revenue and Resources, 96.

${ }^{40}$ Misiura, Heritage Marketing, 15.
} 
media, e-newsletters, brochures, and making advertisements ${ }^{41}$ but also, long-term such as public relations, media visits, creating publications, and organising the annual calendar of festivals and events ${ }^{42}$.

Moreover, the heritage marketer can create new programmes including lectures, workshops, special exhibition openings, and gallery tours. These types of programmes target a large scale of various segments among adults, youth, and children; as well as the participation and support of volunteers and non-governmental associations. On the other hand, there are some target segments which have some preferences like attending concerts and "new exhibitions with opening night events", or to watch the heritage and/or documentary films. ${ }^{43}$

\section{Table 1: Promotion tools and methods ${ }^{44}$}

\begin{tabular}{|c|c|c|c|}
\hline Advertising & Sales Promotion & Direct Marketing & Public Relations \\
\hline $\begin{array}{l}\text { - } \text { Print ads: (magazines, } \\
\text { journals, newspapers) } \\
\text { - } \text { Display advertising } \\
\text { - } \text { Television } \\
\text { - } \text { Packaging } \\
\text { - } \text { Direct mail } \\
\text { - Catalogues:(newsletter, } \\
\text { - } \text { brochures, booklets) } \\
\text { Poster sites (for example, } \\
\text { - } \text { Posters buses, at airports) } \\
\text { - } \text { Directories } \\
\text { - } \text { Reprints of ads } \\
\text { - } \text { Billboards } \\
\text { - } \text { Display signs } \\
\text { - } \text { Point-of-purchase } \\
\text { displays } \\
\text { - } \text { Audiovisual materials } \\
\text { - Symbols and logos } \\
\text { - Guidebooks } \\
\text { Web sites, podcasts, } \\
\text { blogs } \\
\text { - } \text { Aeb advertising:(text } \\
\text { ads, interstitials, opt-in } \\
\text { mailing) } \\
\text { Ad partnerships }\end{array}$ & $\begin{array}{l}\text { - Gifts and premiums } \\
\text { - Exchange privileges } \\
\text { - Discounts } \\
\text { - Tickets } \\
\text { - Gift shop coupons } \\
\text { - Rebates } \\
\text { - Contests }\end{array}$ & $\begin{array}{l}\text { - Direct mail (including } \\
\text { magalogs) } \\
\text { - Database marketing } \\
\text { - Business-to-business } \\
\text { marketing } \\
\text { - Web sites (including } \\
\text { blogs) } \\
\text { - Targeted email marketing } \\
\text { - Drip marketing: sending } \\
\text { multiples by e-mail and } \\
\text { regular mail } \\
\text { - Direct-response TV: } \\
\text { commercials and } \\
\text { infomercials } \\
\text { - Direct- response radio } \\
\text { - Direct- response display } \\
\text { ads } \\
\text { - Promotional videos, } \\
\text { - DVDs } \\
\text { - Mailing lists and e-mail } \\
\text { lists } \\
\text { - Telemarketing } \\
\text { - Viral marketing } \\
\text { - Integrated } \\
\text { M a r k e t i n g Direct }\end{array}$ & $\begin{array}{l}\text { - } \text { Brand image: } \\
\text { - Rago, tagline } \\
\text { - Television } \\
\text { - Press kits } \\
\text { - Speeches } \\
\text { - Seminars } \\
\text { - Annual reports } \\
\text { - Sponsorships } \\
\text { - Publications } \\
\text { - Community } \\
\text { - } \text { relations } \\
\text { - Lobbying } \\
\text { - } \text { Pedia relations } \\
\text { - } \text { adverticing } \\
\text { - Publicity }\end{array}$ \\
\hline
\end{tabular}

\section{Competition Analysis}

In contrast to the business fields, heritage destinations do not consider other heritage attractions as competitors. These heritage attractions require more information about their competitors to attract the public's attention and participation in various forms. The community, either national or international, can join the activities or actions of the heritage site or museum as sponsors, members, volunteers, or to be a regular visitor. Currently, these attractions have started to use various market research tools and information technology techniques in order to assess the current situation of heritage competitors. ${ }^{45}$

\footnotetext{
${ }^{41}$ Cheryl Hargrove, "Distinctive Destination Marketing: Best Practices to Influence Consumer Choices" (Cultural Heritage Tourism Workshops, Hargrove International Inc., 2011), accessedJuly15,2015, www.eriecanalway.org/documents/NYCulturalHeritagTourismMarketing.pdf; Kapil Kumar, "Marketing World Heritage Sites: A Case Study of Product Rejuvenation and Promotion of World Heritage Sites in India," International Journal of Tourism and Travel 7, no. 12/ (2014): 21

${ }^{42}$ Park, Heritage Tourism, 139.

${ }^{43}$ Kotler, Kotler, and Kotler, Museum Marketing and Strategy: Designing Missions, Building Audiences, Generating Revenue and Resources, $298-302$.

${ }^{44}$ Kotler, Kotler, and Kotler, Museum Marketing and Strategy: Designing Missions, Building Audiences, Generating Revenue and Resources, 349.

${ }^{45}$ Kotler, Kotler, and Kotler, Museum Marketing and Strategy: Designing Missions, Building Audiences, Generating Revenue and Resources, 55 , 116.
} 


\section{Marketing Segmentation}

Kotler et al. translated the definition of marketing segmentation from a French book ${ }^{46}$ as

The action of regrouping the units making up a market of sub-groups in such a way that each group is characterized by homogenous needs and that the different groups are separated from each other by virtue of their differing requirements.

Moreover, it was identified the segmentations of possible target customer of the heritage destinations and pinpointed the needs of these segments. Young people, for instance, probably want spending leisure-time for enhancing their recreational experiences while the segments of families seek educational activities for their children. ${ }^{47}$

The segmentation process plays a significant role in the heritage marketing plan. Kotler et al. and Park indicate that within the marketing strategies, it estimates the exact target market attracting and dividing this market to additional groups which the marketing plan probably reaches overall or in particular providing the heritage visitors' needs and wants ${ }^{48}$. The segmentation process may be verified regarding various categories: geographically, demographically, psychographically, behaviorally, occasionally, loyally, organisationally, socio-economically, and culturally ${ }^{49}$.

\section{Second Step: Preparing heritage marketing vision and mission}

The mission statement is strategically focused on which direction the heritage site or museum hope to orient. It identifies the marketing borders of the heritage destination. Moreover, it is a communication tool which within the heritage attraction expresses the marketing techniques of reaching the targeted groups and can serve and satisfy their needs and wants through its facilities, services, its collections, activities, and programmes. ${ }^{50}$ Heritage marketing mission is written through answering four questions: what is offer?, where?, to whom?, and How?

Third Step: Identifying the human resource values for the implementation team of a heritage marketing plan; as well as putting the supposed time and budget.

Fourth Step: Preparing marketinggoals, objectives and their relevance to strategies

Heritage marketing goals are the general statements to identify the ways of accomplishing strategies. These goals in long term shall be most effective serving the marketing strategic plan. ${ }^{51}$ Therefore, the marketing objective is usually considered "not to increase the number of visitors, but rather to manage demand, so that the attraction is not damaged by overuse" ${ }^{52}$

Marketing objectives should be formulated according to the SMART framework, encompassing the characteristics of being Specific, Measurable, Attainable, Relevant, and Time-bound, in order to achieve marketing strategies and goals. "[Marketing objectives] are more effective when derived from a long-term visioning process and goal setting." The heritage and cultural attractions' objectives are usually concerned to preserve the factor of authenticity and integrity to act the pattern of sustainability at the heritage site, to conserve the heritage constructions or objects, and to find out a suitable rapport between the local community and heritage tourism. ${ }^{53}$

\footnotetext{
${ }^{46}$ Mario Beaulac, François Colbert, and Carole Duhaime, Le Marketing En Milieu Museal: Une Recherché Explorattoire (Montreal: Groupe de recherché et de formationen gestion de arts. Ecole des Hautes Etudes Commerciales de Montreal, 1991), accessed August 15, 2015, http://neumann.hec.ca/ artsmanagement/cahiers\%20de\%20recherche/GA9101-A.pdf.

${ }^{47}$ Kotler, Kotler, and Kotler, Museum Marketing and Strategy: Designing Missions, Building Audiences, Generating Revenue and Resources, 24.

${ }^{48}$ Kotler, Kotler, and Kotler, Museum Marketing and Strategy: Designing Missions, Building Audiences, Generating Revenue and Resources, $116,117,129$; Park, Heritage Tourism, 138 .

${ }^{49}$ Kotler, Kotler, and Kotler, Museum Marketing and Strategy: Designing Missions, Building Audiences, Generating Revenue and Resources, $119-27$.

${ }^{50}$ Kotler, Kotler, and Kotler, Museum Marketing and Strategy: Designing Missions, Building Audiences, Generating Revenue and Resources, 88, 90 ; Susan Horner and John Swarbrooke, Leisure Marketing: a Global Perspective (Amsterdam: Routledge, 2004), 167.

${ }^{51}$ Kotler, Kotler, and Kotler, Museum Marketing and Strategy: Designing Missions, Building Audiences, Generating Revenue and Resources, 91 ; Morrison, Marketing and Managing Tourism Destinations, 75.

${ }^{52}$ Horner and Swarbrooke, Leisure Marketing, 193.

${ }^{53}$ Lina Anastassova, "Marketing Heritage Tourism in Less Developed Countries: Problems and Challenges," in The $2^{\text {nd }}$ International Conference on Tourism and Hospitality "Planning and Management Heritage for the Future" (The $2^{\text {nd }}$ International Conference on Tourism and Hospitality, Marriott Putrajaya, Malaysia, 2007); Morrison, Marketing and Managing Tourism Destinations, 76; The Manitoba Electrical Museum \& Education Centre, "Guide to Marketing and Promoting Heritage Organizations," Governmental, Manitoba (Tourism, Culture, Heritage, Sport and Consumer Protection), (2014), 8, accessed May 18, 2015, www.gov.mb.ca/chc/hrb/pdf/heritage_guide_to_marketing.pdf.
} 


\section{Fifth Step: Acting the auditing or monitoring process}

After applying the marketing plan, the auditing process helps, "as a comprehensive, systematic, independent, and periodic examination", the heritage manger to assess, and improve the site performance by identifying problems and opportunities and introducing some suggestions or recommendations to develop the performance of heritage marketing plan. In particular, auditing process is functionally to monitor, review, and evaluate the weaknesses of a heritage site or museum. As a result of auditing, the heritage attraction can balance between the capacity of the heritage destination and the needs and wants of the heritagevisitors. ${ }^{54}$

The implementation structure of heritage marketing plan

\begin{tabular}{|l|l|l|l|l|l|l|l|l|}
\hline Strategy & Goal & Objective & Outcome & Activity & $\begin{array}{l}\text { Time } \\
\text { Frame }\end{array}$ & Cost & Responsibility & $\begin{array}{l}\text { Key } \\
\text { Performance } \\
\text { Indicators } \\
\text { ( K P I s ) }\end{array}$ \\
\hline & & & & & & & & \\
\hline
\end{tabular}

\section{Sixth Step: Heritage Branding}

Heritage branding is the final level of heritage marketing «Augmentation». It is a defensive tool in the competitive marketplace which creates loyalty via developing a direct emotional rapport with the visitors, and charges a suitable price. It is considered a messaging process communicating with the target visitors. The brand message must be «simple, consistent and reinforced by experience» to catch the audiencess eye and upgrade their imagination. To operationalize effectively this message, it requires name, term, sign, symbol, $\log { }^{55}$, slogans / strap lines, taglines, design, advertising, public relations or a collection of these which enhance the recombination of pleasurable memorial experiences of the heritage attraction and sell the site services. ${ }^{56}$ The main function of heritage branding is to illustrate the main characteristics of the heritage destination and to develop the site identity and image overtime in the minds of visitors and other stakeholders. Consequently, «visitors experience the promoted brand values and feel the authenticity of a unique place». ${ }^{57}$

\section{Conclusion}

In sum, the research stated that the inherited past plays culturally a significant part of the present attracting the audience to the heritage product (tangible or intangible). The heritage site or museum might realize this attention within the rate of visitors' participation in the heritage-related edutainment activities and the enhancement level of their heritage experience. But, in order to reach, inform those visitors, catch their desire to visit mainly or involve this heritage attraction, the heritage site or museum requires creatively special marketing activities. Consequently, the author finds the heritage marketing planning, as a tool of attracting who is interested in heritage, is a bridge between the heritage site and its audience exchanging something of value for something they need or want. Furthermore, it seeks satisfying some of the visitors' expectations and motivations and at the same time, transmitting the heritage knowledge for the coming human generations.

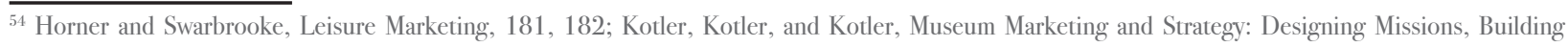
Audiences, Generating Revenue and Resources, 69, 73, 448, 449.

55 "Logo appears on all museum correspondence, promotional and marketing material, and related information, plus the community website and travel brochures" The Manitoba Electrical Museum \& Education Centre, "Guide to Marketing and Promoting Heritage Organizations."

${ }^{56}$ Park, Heritage Tourism, 135, 136; Sam Renbarger, "Brand Heritage Guide," 2012, accessed June 29, 2015, www.slideshare.net/hungrystratgist/ brand-heritage-guide?qid=405713d20-ee34519--abd139-db44b92f44\&v=qf1\&b=\&from_search=1; The Manitoba Electrical Museum \& Education Centre, "Guide to Marketing and Promoting Heritage Organizations," 17.

${ }^{57}$ Kotler, Kotler, and Kotler, Museum Marketing and Strategy: Designing Missions, Building Audiences, Generating Revenue and Resources, 138-42; Misiura, Heritage Marketing, 168-70, 243; Morrison, Marketing and Managing Tourism Destinations, 91; Kumar, "Marketing World Heritage Sites: A Case Study of Product Rejuvenation and Promotion of World Heritage Sites in India," 15.
} 


\section{Acknowledgement}

I appreciate my M.A. supervisors, Prof. Mayada Belal ${ }^{58}$ and Prof. Ping Kong ${ }^{59}$, for their guidance, encouragement and continuing support. Moreover, I thank my colleagues, who assisted me in collecting literature and references, for their assistance such as my colleague Ms. Noha Qotb ${ }^{60}$ who initially supported me with references about heritage marketing; Ms. Baharak Ashrafi ${ }^{61}$ who aided me looking for necessary heritage marketing-related books and articles which were not available in Egyptian libraries; and Ms. Chelsea Solan ${ }^{62}$ who linguistically edited my draft.

\section{Bibliography}

Anastassova, Lina. "Marketing Heritage Tourism in Less Developed Countries: Problems and Challenges." In The 2nd International Conference on Tourism and Hospitality "Planning and Management Heritage for the Future." Marriott Putrajaya, Malaysia, 2007.

Ashworth, Gregory, and Peter Howard, eds. European Heritage Planning and Management. Bristol: Intellect Ltd, 1999.

Baram, Uzi. "Marketing Heritage.” Edited by Claire Smith. Encyclopedia of Global Archaeology, 2014.

Beaulac, Mario, François Colbert, and Carole Duhaime. Le Marketing En Milieu Museal: Une Recherché Explorattoire. Montreal: Groupe de recherché et de formationen gestion de arts. Ecole des Hautes Etudes Commerciales de Montreal,1991.AccessedAugust 15,2015,http://neumann.hec.ca/artsmanagement/cahiers\%20de\%20 recherche/GA91-01A.pdf.

Boyd, Stephen W., and Dallen J. Timothy. "Marketing Issues and World Heritage Sites.” In Managing World Heritage Sites, edited by Anna Leask and Alan Fyall, 1t ed. USA: Elsevier Ltd., 2006.

Butler, R.W. “The Concept of A Tourist Area Cycle of Evolution: Implications for Management of Resources.” The Canadian Geographer 24, no. 1 (1980): 5-12.

Chhabra, Deepak. "Proposing a Sustainable Marketing Framework for Heritage Tourism.” Journal of Sustainable Tourism 17, no. 3 (2009): 317-20.

"Definition of Marketing and Management." UKEssays. Accessed June 26, 2015.www.ukessays.com/essays/ marketing/definition-of-marketing-and-management-marketing-essay-php.

El-Barmelgy, Hesham Mohamed. "Visitor Management Plan and Sustainable Culture Tourism (Presenting the VMP Project for the Cairo Citadel of Salah El Dien).” International Journal of Education and Research 1, no. 12 (2013): 15481.

Fraser, Peter, Finola Kerrigan, and Mustafa Özbilgin. “Key Issues in Arts Marketing.” In Arts Marketing, edited by Finola Kerrigan, Peter Fraser, and Mustafa Özbilgin, ${ }^{\text {st }}$ ed., 187-97. Oxford: Routledge, 2004.

Genoways, Hugh H., and Lynne M. Ireland. Museum Administration: An Introduction. Walnut Creek, Calif: AltaMira Press, 2003.

Hargrove, Cheryl. “Distinctive Destination Marketing: Best Practices to Influence Consumer Choices.” Cultural Heritage Tourism Workshops, Hargrove International Inc., 2011. Accessed July 15, 2015, www.eriecanalway.org/documents/ NYCulturalHeritagTourismMarketing.pdf

Hoggard, Liz. "Arts on the Cheap.” The Guardian (Culture - The Observer). February 9, 2003. Accessed April 20, 2015, www.theguardian.com/theobserver/2003/feb/09/features.review37.

Horner, Susan, and John Swarbrooke. Leisure Marketing: A Global Perspective. Amsterdam: Routledge, 2004.

Kotler, Neil G., Philip Kotler, and Wendy I. Kotler. Museum Marketing and Strategy: Designing Missions, Building Audiences, Generating Revenue and Resources. $2^{\text {nd }}$ ed. San Francisco: Jossey-Bass, 2008.

Kotler, Neil, and Philip Kotler. "Can Museums Be All Things to All People? Mission, Goals, and Marketing's Role." In Museum Management and Marketing, edited by Richard Sandell. London ; New York: Routledge, 2007.

Kotler, Philip. Marketing Essentials. Englewood Cliffs: Prentice-Hall, 1984.

-_-. Marketing Management: Analysis, Planning, Implementation and Control. 9th ed. Upper Saddle River, NJ: Prentice

\footnotetext{
${ }_{58}$ Professor of Tourism Marketing, Faculty of Tourism and Hotel Management, Helwan University.

${ }^{59}$ Advisory Board of Institute of Heritage Studies Member at ICOMOS Germany; International Project Advisor for UNESCO-WHITRAP (Shanghai); Former Visiting Professor of Heritage Management and Economics, Brandenburg University of Technology Cottbus-Senftenberg.

${ }^{60}$ Master of Arts in "Cultural Heritage Management”, The Université Française d"e Egypte and University of Paris 1 Panthéon Sorbonne.

${ }^{61}$ Master of Arts in «World Heritage Studies», Brandenburg University of Technology Cottbus-Senftenberg.

${ }^{62}$ Master of Arts in «World Heritage Studies», Brandenburg University of Technology Cottbus-Senftenberg.
} 
Hall College, 1999.

Kumar, Kapil. "Marketing World Heritage Sites: A Case Study of Product Rejuvenation and Promotion of World Heritage Sites in India.” International Journal of Tourism and Travel 7, no. 1/2 (2014): 14-22.

Lertkulprayad, Lamson. "Marketing Cultural Heritage to Promote Tourism Growth in Areas of Low Tourism Patronage: Case Study of Phetchaburi Province’s Downtown.” PhD, Silpakorn University, 2007.

McCarthy, E. Jerome. Basic Marketing: A Managerial Approach. 7th ed. Georgetown: Irwin, 1981.

Misiura, Shashi. Heritage Marketing. ${ }^{\text {st }}$ ed. London: Routledge, 2006.

Morrison, Alastair M. Hospitality and Travel Marketing. $5^{\text {th }}$ ed. Clifton Park, NY: Delmar Cengage Learning, 2010.

-- - Marketing and Managing Tourism Destinations. $1^{\text {st }}$ ed. New York: Routledge, 2013.

Park, Hyung Yu. Heritage Tourism. $1^{\text {st }}$ ed. London: Routledge, 2014.

Pedersen, Arthur. Managing Tourism at World Heritage Sites: a Practical Manual for World Heritage Site Managers. vol. WH Manuals 1. Paris: UNESCO WHC, 2002. Accessed June 26, 2015, http://whc.unesco.org/uploads/activities/ documents/activity-1 13-2.pdf.

Poria, Yaniv, Richard W. Butler, and David Airey. “The Core of Heritage Tourism.” Annals of Tourism Research 30, no. 1 (2003): 238-54.

Renbarger, Sam. "BrandHeritageGuide."April6,2012.AccessedJune 29, 2015,www.slideshare.net/hungrystratgist/ brand-heritage-guide?qid=405713d2-0ee3-4519-abd1-39db44b92f44\&v=qf1\&b=\&from_search=1.

Rentschier, Ruth. "Museum Marketing, Understanding Different Types of Audiences." In Museum Management and Marketing, edited by Richard Sandell. London: Routledge, 2007.

Rowan, Yorke, and Uzi Baram. “Archaeology after Nationalism: Globalization and the Consumption of the Past." In Marketing Heritage: Archaeology and the Consumption of the Past, edited by Yorke Rowan and Uzi Baram, 3-23. Oxford: AltaMira Press, 2004.

Searles, P.D. "Marketing Principles and the Arts." In Marketing the Arts, edited by Michael P. Mokwa, William M. Dawson, and E. Arthur Prieve, 65-69. New York: Praeger Publishers, 1980.

Smith, Laurajane. “Theorizing Museum and Heritage Visiting.” In The International Handbooks of Museum Studies: Museum Theory, edited by Andrea Witcomb and Kylie Message, $1^{\text {st }}$ ed. vol. 1. Chichester, West Sussex: John Wiley \& Sons, Ltd, 2015.

Strang, R. A., and J. Gutman. "Promotion Policy Making in the Arts." In Marketing the Arts, edited by Michael P. Mokwa, William M. Dawson, and E. Arthur Prieve, 225-39. New York: Praeger Publishers, 1980.

The Manitoba Electrical Museum \& Education Centre. "Guide to Marketing and Promoting Heritage Organizations." Governmental. Manitoba (Tourism, Culture, Heritage, Sport and Consumer Protection), October 31, 2014. AccessedMay18,2015, www.gov.mb.ca/chc/hrb/pdf/heritage_guide_to_marketing.pdf. 